\title{
Takzir as a Punishment in Islamic Criminal Law (Study of the Establishment of Punishment in Criminal Acts in Qanun)
}

\section{$\underline{\text { Usammah }}$}

Islamic Criminal Law Lecturer at the IAIN Lhokseumawe Faculty of Sharia, Indonesia Email: usammah@iainlhokseumawe.ac.id

\begin{abstract}
:
Formalizing the Shari'a of Islam both in the realm of social and social life, in the state and nation are not infrequently debated, both socio-political and religious debates. The debate is in addition to understanding the teachings of religion and its relationship with the nation-state, as well as understanding the existing legal system within the country, especially that the country embraces a positive legal system that is more influenced by western law. The notion of enforcement of Islamic criminal law can not necessarily be carried out properly without any legislation and the establishment of a material Islamic criminal law as a positive law in force. Also, Islamic criminal law is a public law requiring state power both in law making and in law enforcement. In relation to the legislation and the formation of the law (qanun syariat Islam), the most interesting thing is how to determine the shape of the finger and its uqubat both belonging to the category of hudud, qisas and takzir as part of the Islamic Shari' a law enforcement system
\end{abstract}

Keywords :

Al-Quran; takzir; islamic law; hadith

\section{Introduction}

In religion, law is revealed for the good of humanity itself, in order to enclose the creed and morals. The arguments that emphasize the obligation to make Shari'a (God's law) as law in the sense of legislation, so that we increasingly recognize the position of Islamic law and our obligations as adherents to glorify Islamic law and practice it. Islamic Shari'a is a perfect guide as a medium for the mankind in fulfilling its obligations to God. Islamic Shari'a which is revealed by Allah is a Shari'a that fulfills the justice of the mankind, upholds honesty, provides broad benefit for the legal problems of the community, as well as Shari' $a$ h is far from tyranny and certain interests in all laws. As a product of perfect legislation and no one party is able to create or make rules or legislation as complete, as perfect as the Islamic Shari'a revealed by Allah SWT, as referred to in the Quran which means "Your God's sentence (Al-Quran) bas been completed as a true and just sentence. No one can change His sentences and He is the All-Hearing, All-Knowing "(Surah Al-An'am / 6: 115)

Be a benchmark in all work because Islamic law requires a balance between the world and the hereafter, between spiritual needs and physical needs. It is easily practiced, not difficult and not narrow, and also in accordance with the correct logic and human nature. The benefits obtained for those who obey the orders of Allah and the harm that is suffered because of committing immorality or crime and the crime returns to the perpetrators themselves, both as individuals and as community groups. Evil exists in this world together with human existence. The will to do evil is inherent in human life. On the other hand humans want to live in peace, order, peace and justice. It means that it is not disturbed by evil deeds. Human efforts to minimize crime have been carried out, both preventive and repressive. In Islamic teachings discussions about human crime and preventive and repressive efforts are explained in jinayah figh. 
Punishment in Jinayah (Islamic Criminal Law) is often said to be a "cruel" punishment. The law of cutting off hands, stoning, Qisas, and volume is often used as the reason behind this impression, even though in reality, this is almost never done in the history of Islamic criminal law, except in cases of adultery and accusing others of adultery during the Prophet's time and periods very few friends. Therefore, the reality of Islamic criminal law is not as simple as its impression. An in-depth discussion of Islamic criminal law will prove this error. Therefore the application of Islamic law on the basis that Islam is what has been inherited from the books of Figh and that the limits of Allah's law are rigid is an empty cry that only drains time, wealth and energy and mind. (Muhammad Syahrur, 2007: p. 222). In this in-depth discussion, it is seen that not all criminal acts (jarimah) are threatened with budud or qisa, however, in general they are threatened with takzir. Actually, Islamic Criminal Law gives an opportunity for the birth of two different laws in two similar cases, as Islamic Civil Law provides an opportunity for establishing inheritance relations based on social change (Muhammad Syahrur, 2007: p. 222).

Islam prescribes the punishment of takzir as a form of punishment for educative actions against those who commit immoral acts or those who come out of the rules. From that origin, the narration is what was narrated by Abu Dawud, At-Tarmidzi, an-Nasa'i and al-Baihaqi from Bahz bin Hakim from his father from his grandfather that the Holy Prophet had sentenced him to confinement (imprisonment) against false accusations of "badith" this was considered valid by the Judge (Sayyid Sabiq, 2006: p. 492). However, such a sentence as the Prophet's imprisonment is a preventive measure until the case becomes clear. Imam Bukhari, Imam Muslim, narrated the hadith about the application of volume punishment as a form of takzir punishment, which means "Has told us' Abdullah bin Yusuf has told us Al Laits has told me Yazid bin Abu Hubaib from Bukair bin Abdullah from Sulaiman bin Yasarfrom 'Abdurrabman bin Jabir bin Abdullah from Abu Burdah radliallabu' anhu, said; The Prophet sallallaabu 'alaibi wasallam said: "No binding may exceed ten times other than in the wrong sentence (bad) of Allab (set) (Ahmad Ali Ibn Asqalani, 1408:p. 182)."

Takzir is a punishment that is not contained in the Qur'anic text or Hadith that explains about its provisions, so that a judge is given the freedom to decide on a sentence against a case. The Qur'an and the Hadith of the Prophet have not explained about every act that is happening now and in the future, both of them only explain about the law of a case that occurred at that time. So that when there is a change in the condition, it needs new ijtihad which may result in a decision that an action is considered wrong that was not previously considered wrong, or punish someone with a more severe sentence or with a lighter sentence (Al-'Asymâwi, 1983: p. 129).

\section{Methodology}

In this discussion and writing using empirical normative methods, this study views the law (Qanun) in its form that determines what is permissible and what is not permitted, is prescriptive in nature, also determines what is wrong and what is right (Achmad Ali and Wiwie Heryani , 2013: pp. 1-6). Empirical studies see law as reality, including social reality, cultural reality, are descriptive in nature. The approach used is the legal approach that is the Law / Qanun approach (statute approach), conceptual approach (conceptual approach) and also the case approach (Peter Mahmud Marzuki, 2005: p. 93). Data Sources required from various reference materials that are closely related to the title above, namely the Jinayat Law Qanun, books or books of Tasyri 'Jinayat and supplemented with some materials and supporting books that are directly or unrelated with this problem, while the data source implied in the form of legal materials derived from dictionaries, the internet and also encyclopedias. Data sources are collected and processed in the form of literature studies, through the stages of identification and inventory. 


\section{Discussion}

\subsection{The form and type of Takzir's actions in the System of Determination of Qanun.}

In criminal law, we recognize two forms of retaliation (jazâ) for the perpetrators of criminal acts, the first is to provide penalties and the second is in the form of acts of incentive or rehabilitation. In this section, we will focus more on punishment, which is one of the two instruments above. From the above statement, we can know that punishment is one of the instruments in criminal law as a form of retaliation for criminals, because it is a representation of the people's resistance against criminals and their crimes. Therefore, when we agree that the criminals and the crimes they commit are objects of criminal responsibility (al masúliyah al jinâiyah) then when someone is proven to have committed a criminal act, this requires the conviction of these perpetrators. That is because criminal acts in the form of violations of the rules and norms that exist in society and which have resulted in anxiety in the community. Require the subject of criminals to be subject to punishment. Because it is something that we cannot accept if the perpetrators of crimes roam the middle of society while spreading damage without any obstruction. This is on the one hand, while on the other hand so that the rule of law as a guideline for people's lives can be upheld and respected by the community, there must be penalties for those who violate these legal norms. For more details, so that we are more familiar with punishment, then we will try to discuss it, especially the discussion relating to matters that are the principle of punishment. So therefore we will discuss it from the start of the definition, characteristics, objectives, and conviction.

Punishment in Islamic law for four kinds of views of its purpose, namely; (Abdul Qadir, 1996: p. 632)

a) Based on the ties or ties of one law to another.

b) Based on the judge's power in determining the form and number of sentences.

c) Based on the obligation to impose penalties.

d) Based on the place where the sentence was carried out; this penalty concerns the implementation of the physical / body or soul of the offender and also the property of the offender.

Takzir is also part of the form of punishment determined by Qanun. Criminal acts that have been determined the type of punishment in the form of takzir are acts which other that mentioned in budud and qisas. Takzir is a sentence imposed on people who violate Shari'a in addition to budud and qisas / diat, this can be seen in several Qanun that have been ratified by the Government of Aceh together with the Aceh Legislative Council (DPR Aceh). as; Qanun No. 5/2000; No.10 / 2002; No. 11/2002; No. 12/2003; No. 13/2003; No. 14/2003, and part of it is in Qanun No. $6 / 2014$. What has been determined in the Qanun, is part of the determination of the punishment in the form of takzir or qisas or budud. Considering that Aceh as part of the Unitary State of the Republic of Indonesia (NKRI) is not very easy to directly apply Islamic Law as the legal basis in the Aceh region, however the implementation of the Shari'a is an indication that Aceh has implemented Islamic Shari'a-based laws, as evidenced in the Kingdom of Aceh Darussalam who was once victorious by implementing Islamic Sharia law. At present the implementation and enforcement of the law through Qanun is still limited to the form of takizir punishment, this means that Aceh is not yet fully, especially residents who live in Aceh to be ready in accepting Islamic law. This unpreparedness was then misinterpreted in the form of the implementation of the Qanun in the form of punishment (Caning) which was considered to have occurred human rights violations. If the execution of punishment in the form of budud and qisas even takzir is carried out in the form of a whip (caning with rattan). 
In Qanun, the type of punishment included as material punishment is more in the form of takizir punishment, so that the punishment given will fulfill the material Qanun and Customs as a whole. The application of the contents of the Qanun through the application of punishment as a form of reaction to the actions of prohibited acts to fulfill a sense of justice for the community. From that the punishment contained in the Qanun consists of; (a) Caning. This punishment is carried out by beating the condemned (violator of the Shari'a after getting a permanent verdict from the Syar'iyah Court), at least 12 times and at most 200 lashes. 200 lashes is a combination of budud punishment which is added with takzir punishment if the act done is a repetition of jarimah hudud. Flogging in the Qanun is the main form of punishment that must be carried out when a person who commits Jarimah has been determined by the Shari'a Court (Mohd. Din, 2009: p. 143). (b) Penalty for fines. Penalty is one type of criminal that has long been accepted in the legal system of the peoples of the world. Although the settings and how to apply it varies according to conditions and development. The penalty is a minimum of 40 grams of pure gold (equivalent to 13.3 grams of gold) and a maximum of 1,750 grams of gold (equivalent to 583.3 grams of gold). (c) Imprisonment. Is a form of punishment that is to eliminate the right of freedom of a person by entering in a prison. Prison sentences of at least 12 months and a maximum of 200 months.

Overall implementation, application and enforcement of Islamic Shari'a law in Aceh is related to aspects contained in various aspects of life in Aceh, the implementation of Indigenous life and culture integrated with Islamic Shari'a is contained in local regulation No. 7/2000 and Qanun No. 12/2004; The fields of aqidah, worship and symbols of Islam are contained in Qanun No. 11 of 2000; The prohibition on drinking khamar or drinking intoxicating drinks is contained in Qanun No. 12 of 2003; The prohibition of gambling or gambling is contained in Qanun No. 13 of 2003; The prohibition on khalwat or nasty is contained in Qanun 14 of 2003; Management and organization of zakat are contained in Qanun No. 7/2004 and Governor's Letter No. 4451.12 / 1227370/2002; Cultivating the prosperity of the Mosque and meunasah can be found in Governor Instruction No. 05 / INSTR / 2000; The necessity of reading the Al-Quran and understanding local customs for elementary school students is contained in Governor's Instructions No. 02 / INSTR / 1990; The implementation of alms salary / services for all employees / employees in the Government environment is contained in the Governor's Instructions No. 02 / INSTR / 200; The prohibition of gambling, aftermath, betting and the like is contained in Governor's Instruction No. 04 / INSTR / 2002; Arrangement of association / seclusion between men and women contained in the Governor's Instructions No. 05 / INSTR / 2002 and the implementation of congregational prayers in the office / agency / agency / agency / government service environment is contained in the Governor's Instructions No. 06 / INSTR / 2002 (Headar Nashir, 2013: p. 350), and many others that make the legal basis in carrying out various activities that lead to actions that are contrary to the law.

From what has been designed in the Qanun, several types and forms of prohibited acts (violation of Sharia) both in the category of budud and takzir punishment, then it looks like what is arranged in the Qanun, which in principle is an acceleration of what is obligatory the judiciary to determine the punishment for the act through an appropriate and correct legal process. Among the types of violations as contained in the Jinayat Qanun include;

1) Violation of acts of maisir (gambling).

2) Violation of khalwat.

3) Violation of Ikbtilath's actions;

4) The act of sexual harassment;

5) Violations of acts in the form of liwath;

6) Violations of rape; 
7) Violations of acts that have been regulated in Qanun Number 11 Year 2002 Concerning the Implementation of Islamic shari'a in the areas of Aqidah, Worship and Symbols of Islam.

\subsection{Provisions for the punishment of takzir on criminal offenses in the Qanun.}

The takizir punishment is determined according to the level of the crime based on the things that are known by the judge on the takzir's rahmah, both the condition of the person to be sentenced, the fact of the crime that has occurred and the place of the crime so that the sentence to be imposed must be based on the achievement of the objective of the punishment namely prevention. Thus this takiir punishment is a jurisdiction that must be filled by using the knowledge, intelligence and thinking ability of judges to perform jihad and determine their own forms of punishment in accordance with socio-cultural conditions within the framework of the instructions of the texts and shari'a principles. The characteristics of takzir law shows that criminal capacity has a level of elasticity and flexibility that is able to deal with the development of society and changes in situations and conditions so that the shari'ab is suitable to be applied in accordance with its conceptuality. Therefore, there are two characteristics of takzir punishment for the present, namely (1) as an answer to the problems of contemporary society; the concept of takzir law is the area of law that Allah SWT deliberately gives freedom to humans to determine for themselves what actions need to be determined as prohibited acts and what penalties are appropriate to be imposed by those prohibited acts. For the legal needs of modern society where life has developed so rapidly along with the advancement of science and technology, of course the legal needs are also developing following the development of society, where it is not enough just about the provisions of budud and qisas / diat, but there needs to be a measure of law in other fields of life which is very very broad and many in accordance with the legal needs of society itself. (2) The authority of the Government to stipulate takzir for the purpose of upholding the amar ma'ruf nabi mungkar. The punishment of takzir which is the authority of waliyul amri (government / ruler) is expected so that the government can regulate the community. In this case Ibn Taymiyyah argued: "It must be known that the authority of leadership including religious obligations and even religion and the world will not stand except with him, because in fact the benefit of humanity will not be realized except by gathering (social), because they need each other.

The punishment of takzir is different from the punishment of hadd (budud) in terms of 3 (three) aspects; first, the punishment of takzir differs according to different levels of people, for people who have a seat will not be the same punishment with people who are low ranking; secondly, asking for clemency in relation to his sentence takeir is permissible whereas in had had punishment is not permitted; third, in takzir punishment if there is injury then the priest must pay compensation (Salim, Abd. Rasyid, 2007: p. 135). This opinion is different from the opinion in the circles of Imam Abu Hanifa and Imam Malik, who consider the punishment of takizir and the sentence of educating relatively to have the same purpose but different in explaining it.

In Islamic law, the system of applying legal sanctions is carried out through two types of sanctions, namely (1) definitive punishment from Allah and the Apostle and sanctions imposed by humans through governmental authorities who are entitled to determine their laws such as executive, legislative and judicial bodies (Justice). Both types of sanctions imply the community to obey and obey the provisions of the law in force. In many cases law enforcement demands the role of the state. The law does not work if it is not enforced by the State. On the other hand a country will be disorderly if the law is not enforced. 
With regard to the deeds set out in the Jinayat Qanun regarding jinayat, the determination of the sanctions (uqubat) does not adhere to the principle of alternative or optional uqubat, because sanctions are definitive based on the arguments of the quran or hadith. While the deeds of rabmab takzir adhere to the principle of alternative uqubat punishment, namely caning, fines and imprisonment, even takzir punishment in other forms other than the three types. Based on the foregoing, qanun jinayat in the case of establishing budud uqubat for adultery is whipped 100 times, for khamar drink is whipped 40 times, while for the same Jarimah deed there is a repetition then takezir punishment is stipulated as an additional punishment based on qanun for whipping judge's decision.

The following is a description of the amount of the punishment for each form of his tomb as stated in Qanun Number 6 of 2014 concerning Jinayat.

\begin{tabular}{|c|c|c|c|c|c|}
\hline \multirow{2}{*}{ NO } & \multirow{2}{*}{$\begin{array}{l}\text { TYPES OF } \\
\text { JARIMAH }\end{array}$} & \multirow{2}{*}{ KINDS OF JARIMAH } & \multicolumn{2}{|c|}{ TYPE OF PUNISHMENT } & \multirow{2}{*}{ ARTICLE } \\
\hline & & & HUDUD & TAKZIR & \\
\hline \multirow[t]{3}{*}{01} & \multirow[t]{3}{*}{ Khamar } & Intentionally & Whip 40 times & $\begin{array}{l}\text { Whip } 40 \text { times or } \\
\text { A fine of } 400 \text { grams of pure gold or a } \\
\text { prison of } 40 \text { months }\end{array}$ & \multirow[t]{3}{*}{$\begin{array}{l}\text { Article } 15, \\
16,17\end{array}$} \\
\hline & & $\begin{array}{l}\text { Producing / storing / } \\
\text { stockpiling and selling }\end{array}$ & & $\begin{array}{l}\text { Whip } 60 \text { times or } 600 \text { grams of fine } \\
\text { gold fine or } 60 \text { months imprisonment }\end{array}$ & \\
\hline & & Buy / transport / gift & & $\begin{array}{l}\text { Whip } 20 \text { times or fine of } 200 \text { grams } \\
\text { of pure gold or jail } 20 \text { months }\end{array}$ & \\
\hline \multirow[t]{3}{*}{02} & \multirow[t]{3}{*}{$\begin{array}{l}\text { Maisir } \\
\text { (Perjudian) }\end{array}$} & $\begin{array}{l}\text { Accidentally (with a bet of } 2 \\
\text { grams of pure gold) }\end{array}$ & & $\begin{array}{l}\text { Whip } 12 \text { times or fine } 120 \text { grams of } \\
\text { pure gold or } 12 \text { months } \\
\text { imprisonment }\end{array}$ & \multirow{3}{*}{$\begin{array}{l}\text { Artice 18, } \\
19,20,21 \\
22\end{array}$} \\
\hline & & $\begin{array}{l}\text { Deliberately (betting more } \\
\text { than } 2 \text { grams of pure gold) }\end{array}$ & & $\begin{array}{l}\text { Whip } 30 \text { times or fine } 300 \text { grams of } \\
\text { pure gold or } 30 \text {-month prison }\end{array}$ & \\
\hline & & $\begin{array}{l}\text { Organize / provide facilities } \\
\text { and include children }\end{array}$ & & $\begin{array}{l}\text { Whip } 45 \text { times or fine } 450 \text { grams of } \\
\text { pure gold or Jail } 45 \text { months }\end{array}$ & \\
\hline \multirow[t]{2}{*}{03} & Khalwat & Intentionally & & $\begin{array}{l}\text { Whip } 10 \text { times or fine } 100 \text { grams of } \\
\text { pure gold or } 10 \text { months } \\
\text { imprisonment }\end{array}$ & \multirow[t]{2}{*}{$\begin{array}{l}\text { Article } 23 \\
\text { dan } 24\end{array}$} \\
\hline & & Organize / provide facilities & & $\begin{array}{l}\text { Whip } 15 \text { times or fine of } 150 \text { grams } \\
\text { of pure gold or jail } 15 \text { months }\end{array}$ & \\
\hline \multirow[t]{3}{*}{04} & \multirow{3}{*}{$\begin{array}{l}\text { Ikhtilath } \\
\text { (bercumbu/ } \\
\text { bemesraan/ } \\
\text { berpelukan/ } \\
\text { berciuman } \\
\text { bukan suami- } \\
\text { istri) }\end{array}$} & Intentionally & & $\begin{array}{l}\text { Whip } 30 \text { times or fine } 300 \text { grams of } \\
\text { pure gold or } 30 \text {-month prison }\end{array}$ & \multirow{3}{*}{$\begin{array}{l}\text { Article } 25, \\
26,27,28 \\
29,3031 \\
32\end{array}$} \\
\hline & & $\begin{array}{l}\text { Organizing facilities and also } \\
\text { involving children }\end{array}$ & & $\begin{array}{l}\text { Whip } 45 \text { times or fine } 450 \text { grams of } \\
\text { pure gold or Jail } 45 \text { months }\end{array}$ & \\
\hline & & $\begin{array}{l}\text { Making Confessions to } \\
\text { Conduct Ikhtilath } \\
\text { Accusing People of } \\
\text { Conducting Ikthtilath }\end{array}$ & & $\begin{array}{l}\text { Whip } 45 \text { times or fine } 450 \text { grams of } \\
\text { pure gold or Jail } 45 \text { months }\end{array}$ & \\
\hline
\end{tabular}


Britain International of Humanties and Social Sciences (BIoHS) Journal

ISSN: 2685-3868 (Online), 2685-1989 (Print)

Vol. 1, No. 2, October 2019, Page: 100-108

\begin{tabular}{|c|c|c|c|c|c|}
\hline & & & & $\begin{array}{l}\text { Whip } 30 \text { times or fine } 300 \text { grams of } \\
\text { pure gold or } 30 \text {-month prison }\end{array}$ & \\
\hline \multirow[t]{4}{*}{05} & \multirow[t]{4}{*}{ Zina } & Intentionally & Whip 100 times & & \multirow{4}{*}{$\begin{array}{l}\text { Article } 33, \\
34,35,36, \\
37,38,39, \\
40,41,42, \\
43,44,45\end{array}$} \\
\hline & & Repeat deeds & Whip 100 times & $\begin{array}{l}\text { A fine of } 120 \text { grams of pure gold or a } \\
12 \text {-month prison }\end{array}$ & \\
\hline & & Providing facilities & & $\begin{array}{l}\text { Whip } 100 \text { times or fine of } 1000 \\
\text { grams of pure gold or Jail } 100 \\
\text { months }\end{array}$ & \\
\hline & & $\begin{array}{l}\text { Doing with Children, also } \\
\text { with mahram }\end{array}$ & & $\begin{array}{l}\text { Whip } 100 \text { times or fine of } 1000 \\
\text { grams of pure gold or Jail } 100 \\
\text { months }\end{array}$ & \\
\hline \multirow[t]{2}{*}{06} & \multirow[t]{2}{*}{$\begin{array}{l}\text { Pelecehan } \\
\text { Seksual }\end{array}$} & Intentionally & & $\begin{array}{l}\text { Whip } 100 \text { times or fine of } 1000 \\
\text { grams of pure gold or Jail } 100 \\
\text { months }\end{array}$ & \multirow[t]{2}{*}{$\begin{array}{l}\text { Article 46, } \\
47\end{array}$} \\
\hline & & Doing with Children & & $\begin{array}{l}\text { Whip } 90 \text { times or fine } 900 \text { grams of } \\
\text { pure gold or Prison } 90 \text { months }\end{array}$ & \\
\hline \multirow[t]{3}{*}{07} & \multirow[t]{3}{*}{ Pemerkosaan } & Intentionally & & $\begin{array}{l}\text { Whip } 125 \text { times or Fine } 1,250-1,750 \\
\text { grams of pure gold or Jail } 125-175 \\
\text { months }\end{array}$ & \multirow{2}{*}{$\begin{array}{l}\text { Article } 48, \\
49,50,51, \\
52,53,54, \\
55,56\end{array}$} \\
\hline & & $\begin{array}{l}\text { Deliberately with people } \\
\text { who have a mahram } \\
\text { relationship }\end{array}$ & & $\begin{array}{l}\text { Whip 150-200 times or a fine of } \\
1,500-2,000 \text { grams of pure gold or Jail } \\
150-200 \text { months }\end{array}$ & \\
\hline & & Doing with Children & & $\begin{array}{l}\text { Whip 150-200 times or a fine of } \\
1,500-2,000 \text { grams of pure gold or Jail } \\
150-200 \text { months }\end{array}$ & \\
\hline \multirow[t]{2}{*}{08} & \multirow[t]{2}{*}{ Qadzaf } & Intentionally & Whip 80 times & & \multirow{2}{*}{$\begin{array}{l}\text { Article 57, } \\
58,59,60 \\
61,62\end{array}$} \\
\hline & & Repeat deeds & & 400 grams of pure gold restitution & \\
\hline \multirow[t]{3}{*}{09} & \multirow[t]{3}{*}{ Liwath } & Intentionally & & $\begin{array}{l}\text { Whip } 100 \text { times or fine of } 1000 \\
\text { grams of pure gold or Jail } 100 \\
\text { months }\end{array}$ & \multirow[t]{3}{*}{ Article 63} \\
\hline & & Repeat deeds & & $\begin{array}{l}\text { Whip } 100 \text { times or a fine of } 120 \\
\text { grams of pure gold or } 12 \text { months } \\
\text { imprisonment }\end{array}$ & \\
\hline & & Doing with Children & & $\begin{array}{l}\text { Whip } 100 \text { times or fine of } 1000 \\
\text { grams of pure gold or Jail } 100 \\
\text { months }\end{array}$ & \\
\hline \multirow[t]{2}{*}{10} & \multirow[t]{2}{*}{ Musahaqah } & Intentionally & & $\begin{array}{l}\text { Whip } 100 \text { times or fine of } 1000 \\
\text { grams of pure gold or Jail } 100 \\
\text { months }\end{array}$ & \multirow[t]{2}{*}{ Article 64} \\
\hline & & Repeat deeds & & $\begin{array}{l}\text { Whip } 120 \text { times or fine } 1200 \text { grams } \\
\text { of pure gold or } 12 \text { months } \\
\text { imprisonment }\end{array}$ & \\
\hline
\end{tabular}




\begin{tabular}{|l|l|l|}
\cline { 2 - 3 } & Doing with Children & $\begin{array}{l}\text { Whip 100 times or fine of 1000 } \\
\text { grams of pure gold or Jail 100 } \\
\text { months }\end{array}$ \\
\hline
\end{tabular}

What is encouraging to regard an act as Jarimah is because it can be detrimental to the community's rules or beliefs or detrimental to the life structure of other community members. An immoral act is threatened with punishment by someone who does it so that it becomes a warning to other people so that they do not commit a tomb, because restrictions or orders are not enough. In summary, the basis for prohibiting an act is the maintenance of the community's interests.

\section{Conclusion}

In the Qanun punishment is called the term uqubat. Uqubat is a punishment determined by a judge for a violator of the rabmah qisas - diat, hudud and takzir. Criminal acts (violation of Shari'a) are determined as types of actions that can be punished with Hadd and Takzir penalties, acts that are punished with Hadd or Hudud penalties are penalties that have obtained legal certainty both in number and type of actions and it has been determined by Al -Quran and Hadith. However, actions which are not mentioned in the Al-Quraan and Hadith or contain doubt, then these actions are punished by the punishment of Takzir. The state of the action is included in the Qanun as an action which is categorized by the act of takzir.

The takir punishment is determined according to the level of the crime based on the things that are known by the judge on the takmaher's rahmah, both the condition of the person to be sentenced, the fact of the crime that has occurred and the place of the crime so that the sentence to be imposed must be based on the achievement of the objective of the punishment namely prevention. Thus this takizir punishment is a jurisdiction that must be filled by using the knowledge, intelligence and thinking ability of judges to perform jihad and determine their own forms of punishment in accordance with socio-cultural conditions within the framework of the instructions of the texts and shari'a principles. All concepts and theories regarding criminal that have existed and developed from the classical to the modern one including criminological and victimological theories as long as they do not conflict with the basic principles of shari'a, can be considered and accommodated as discourse that can be discussed to enrich the concept of criminal takzir. The characteristics of takzir law indicate a criminal capacity that has a level of elasticity and flexibility that is able to deal with the development of society and change the situation and conditions so that the shari' $a$ is suitable to be applied in accordance with its contextuality.

\section{References}

A. Djazuli, Fiqh Jinayah; Upaya Menanggulangi Kejahatan dalam Islam, cet. III, Jakarta: Raja Garfindo Persada, 2000.

Abd al-Qadir 'Audah, al-Tasyri' al-Janai al-Islami: Muqaranah bi al-Qanun al-Wadh'i, Beirut: Muassasah al-Risalah, 1996.

Abd. Rasyid Salim, Meraih Jalan Petunjuk; Syarah Bulughul Maram, terj. Bahrun Abubakar Ihsan, jilid 3, Cet. Ke 10, Bandung: Nuansa Aulia, 2007.

Ahmad Ali Ibnu 'Asqalani, Fathul Bari, Syarah Shabih Imam Abi Abdullah Muhammad ibnu Ismail Bukhari, Juz. 12, al maktabah salafi, 1408.

Achmad Ali dan Wiwie Heryani, Menjelajabi Kajian Empiris terhadap Hukum, Cet. ke-2, Jakarta: Kencana Prenamedia Group, 2013).

Al-'Asymâwî, al-Syarîa al-Islâmiyyaț wa al-Qânûn al-Masry, Kairo: Madbuli, 1996. , Ushûl al-Syarîat, Kairo: Madbuli, 1983. 
Hasbi Shiddiqi, Pidana Mati dalam Syari'at Islam, Cet.I, Semarang : Pustaka Rizki Putra, 1998.

Headar Nashir, Islam Syariat; reproduksi salafiyah ideologis di Indonesia, Cet. I, Bandung: Mizan Pustaka, 2013.

Mahmud Syaltout, Islam Sebagai Aqidah dan Syari'ah,jilid 3, Jakarta: Bulan Bintang, 1969.

Marzuki, Peter Mahmud, Penelitian Hukum, Jakarta: Kencana Prenada Media Group, 2005. , Penelitian Hukum, Cet, II, Jakarta: Kencana Prenada Media Group, 2006.

Muhammad Syahrur, Prinsip dan Dasar Hermeneutika Hukum Islam Kontemporer, ed. Sahiron Syamsuddin, Cet. I, Yogyakarta: elSAQ Press, 2007.

Mohd. Din, Stimulasi Pembangunan Hukum Pidana Nasional dari Aceh Untuk Indonesia, Bandung: Unpad Press, 2009.

Ridwansyah, Penghukuman dan Perlindungan HAM dalam Hukum Pidana Islam, Disertasi, Pascasarjana IAIN Ar-Raniry Banda Aceh, 2012.

Salim, Abd. Rasyid, Penjr. Bahrun Abubakar Ihsan, Meraih Jalan Petunjuk Syarah Bulughul Maram, Jilid 3, Cet. Ke 10, Bandung: Nuansa Aulia, 2007

Sayyid Sabiq, Fiqih Sunnah, Jilid 3, Pengt. Hasan al-Banna, Cet. I, Jakarta: Pena Pundi Aksara, 2006. Syahrizal, dkk, Dimensi Pemikiran Hukum dalam Implementasi Syariat Islam di Aceh, Cet. ke-2, Banda Aceh: Dinas Syariat Islam Propinsi Nanggroe Aceh Darussalam, 2011.

Topo Santoso, Menggagas Hukum Pidana Islam, Penerapan Syari'at Islam dalam Konteks Modernitas, Cet. II, Bandung: Asy-Syamil Press dan Grafika, 2001.

Qanun Nomor 6 Tahun 2014 Tentang Hukum Jinayat.

Qanun Nomor 7 Tahun 2013 Tentang Hukum Acara Jinayat.

Keputusan Gubernur Nomor 01 Tahun 2004 Tentang Organisasi dan Tata Kerja Wilayatul Hisbah 